Northwest Journal of Teacher Education

Volume 14 | Issue 2

Article 2

January 2019

\title{
The Impact of Attending an Equity-Based \\ Conference on One Teacher Educator: Five \\ Pedagogical Changes of Practice
}

Rebecca Smith

University of Portland, smithre@up.edu

Follow this and additional works at: https://pdxscholar.library.pdx.edu/nwjte

Part of the Adult and Continuing Education Commons, Adult and Continuing Education and Teaching Commons, Curriculum and Instruction Commons, Curriculum and Social Inquiry Commons, Higher Education and Teaching Commons, and the Scholarship of Teaching and Learning Commons Let us know how access to this document benefits you.

\section{Recommended Citation}

Smith, Rebecca (2019) "The Impact of Attending an Equity-Based Conference on One Teacher Educator: Five Pedagogical Changes of Practice," Northwest Journal of Teacher Education: Vol. 14 : Iss. 2 , Article 2. DOI: https://doi.org/10.15760/nwjte.2019.14.2.2

This open access Article is distributed under the terms of the Creative Commons Attribution-NonCommercialShareAlike 4.0 International License (CC BY-NC-SA 4.0). All documents in PDXScholar should meet accessibility standards. If we can make this document more accessible to you, contact our team. 


\section{The Impact of Attending an Equity-Based Conference on One Teacher Educator: Five Pedagogical Changes of Practice

\author{
Rebecca Smith \\ University of Portland
}

This article is a reflective overview of five pedagogical practice changes that one teacher educator made after attending a multicultural education conference. The article integrates current research to highlight the educational benefits of innovative, equity-based instructional strategies. The pedagogical changes are explored through the theoretical lens of culturally relevant pedagogy (Ladson-Billings, 1995; Gay, 2010) and culturally sustaining pedagogy (Paris \& Alim, 2017) and include: diversifying curriculum, engaging with community partners, collaborating with K-12 practitioners, innovative technology, and self-reflection.

Keywords: Culturally relevant pedagogy, culturally sustaining pedagogy, preservice teacher preparation

\section{Introduction}

Teaching with an equity lens and working to develop myself as a reflective practitioner are core principles in my pedagogical practice. I am an educator of educators, an Assistant Professor of Education at a small, liberal arts university in the Pacific Northwest. I teach undergraduate, Master's, and Doctoral students in our various programs. I come to this higher education work after being a middle and high school teacher for years, and I bring my lived experiences to my pedagogy and practice. My positionality as a White female from a privileged background inform my own teaching and learning, and I know there is always much more to learn and many more ways to grow. This reflective essay is one exemplar of my own professional learning; it is an attempt at critical self-reflection with a goal of building inclusive communities of practice, connecting with others longing for equity in education, and providing ideas that others searching for change may utilize in their own practice.

\section{Starting the Semester}

On the first night of class in nearly all my teacher preparation courses, I share two documents with my students that help establish a common foundation that supports our community learning throughout the semester, especially surrounding discussions of race and equity. One resource is the Racial Consciousness Flow Chart from Singleton and Linton's (2006) 
Courageous Conversations About Race. This chart demonstrates the various steps of awareness from which individuals can vacillate in consciousness about race, including: I don't know what I don't know and I don't know but I think I do. These two steps recognize that we share beliefs and opinions from our own lived experiences that may include incorrect assumptions regarding race and may result in "a myopic and distorted view of others" (Singleton \& Linton, 2006, p. 56). The goal in engaging in courageous conversations about race is to move to the stage of $I$ know $I$ know, which involves the desire and authentic engagement in experiences that may challenge our preconceptions and help us become more aware of the impact of our interactions on students, parents, and colleagues from various racial identities. This Racial Consciousness Flow Chart provides language for our class to use throughout the course when we are reflecting on challenging issues, often learning about our own biases that we "don't know we don't know."

The second document I share with my class, also from Singleton and Linton's (2006) text, is the four agreements of courageous conversation: stay engaged, experience discomfort, speak your truth, and expect and accept non-closure (p. 58). These agreements again provide language for all of us to use when we inevitably experience each of these circumstances throughout the course. These agreements also provide a warning or a preview for students in what to expect. Teacher candidates become aware that they will not always feel comfortable or settled when we discuss issues surrounding race; rather, the discomfort is a demonstration of learning. Throughout the course, we utilize case studies, field experiences, empirical and theoretical research articles, Restorative Justice circles, current events, and stories from our own lived and student teaching experiences to engage in critical discussions surrounding issues of equity. With the parameters and vocabulary in place to engage in productive, respectful dialogue, the potential for transformational learning is present. Critical reflection can enhance and transform adult learning experiences and can lead to changes in practice (Dewey, 1997; Mezirow, 2003), and reflecting on reflection has been shown to enhance teacher candidate awareness of their unconscious biases and how they interact with students (Smith \& Glenn, 2016).

\section{Culturally Relevant and Sustaining Pedagogy}

Systemic inequities must be addressed from numerous angles, and culturally responsive pedagogy (CRP) is one teaching practice that has seen positive impacts in education (Gay, 2010). CRP is a "dynamic process" that "has many different shapes, forms, and effects" (p. 2). LadsonBillings (2014) defines CRP within three domains:

1) Academic success: intellectual growth experienced by students as a result of classroom learning;

2) Cultural competence: the ability for students to know and appreciate their culture of origin while also celebrating the cultures of others; and

3) Sociopolitical consciousness: students' abilities to identity, analyze, and solve realworld problems, thus taking learning beyond the walls of the classroom.

A culturally responsive classroom has "effective teaching and learning [which] occur in a culturally supported, learner-centered context, whereby the strengths students bring to school are identified, nurtured, and utilized to promote student achievement" (Richards, Brown, \& Forde, 2007, p. 64).

More recent research on CRP comes from Paris and Alim's (2017) "loving critique" of CRP (p. 9), Culturally Sustaining Pedagogies (CSP). CSP challenges educators and institutions to go beyond examining pedagogies and actually challenging the inherent injustices of schooling 
itself. CSP calls for "reimagin[ing] schools as sites where diverse, heterogeneous practices are not only valued but sustained" (p. 3). CSP calls on oppressive white institutions to examine the purpose of learning and to view the "outcome of learning as additive rather than subtractive, as remaining whole rather than framed as broken, as critically enriching strengths rather than replacing deficits" ( $\mathrm{p} 1)$.

\section{The Need to Create Culturally Sustaining Preservice Teacher Educators}

Structured equity work is essential to creating spaces for our preservice candidates to share their own racial lived experiences, no matter their racial identities. The majority of preservice teacher preparation candidates in our program are female $(80 \%)$ and $79 \%$ self-identify as White. These demographics reflect national statistics, as teachers in the U.S. currently identify as $80 \%$ White and $77 \%$ female (Taie \& Goldring, 2018), while the student population in U.S. public schools is 50\% White, 16\% Black, and 25\% Latino (U.S. Department of Education, 2014). Research from the Harvard Civil Rights Project (Frankenberg, Lee, \& Orfield, 2003) found numerous educational disparities between White students and students of color, such as higher dropout rates in students of color, overrepresentation in special education of students from underrepresented groups, and a higher percentage of White and Asian students attending and graduating from college. Beginning a preservice teacher preparation class with language that provides a platform for honest and reflective dialogue to address educational inequities helps establish an inclusive learning environment in order to foster thoughtful discussions that empower teacher candidates to be change agents.

Introducing my students in the first class to language about how to engage in discussions about race is followed by a revelation of my own positionality. I realize that I am a White woman in a White female dominated profession, teaching a majority of White females who will become teachers, who will teach predominantly students of color. There is deep-seeded injustice in this reality that stems from the historical racism on which our country was founded. My own critical reflection and research on Whiteness has taught me that "identity is ... situated as one of the core struggle concepts of critical pedagogy, where the formation of self serves as the basis for analyses of race, class, gender, and sexuality and their relationship to the questions of democracy, justice, and community" (Anglás Grande, 2017, p. 219). My struggle to become a critical pedagogue and to help develop culturally engaged teachers must focus on developing an understanding of myself. I recognize the position I have to integrate equity into my own curriculum and instruction as much as I am able. My work to become a critically conscience educator will never end, but with the help of professional learning experiences and expert voices in the field who continue to teach and guide me, in addition to my own students' feedback, I continue to grow and learn.

One key learning experience that I engaged in last year was the annual National Association for Multicultural Education (NAME) conference. This conference challenged me as a preservice teacher educator to critically reflect on my own beliefs and teaching practices, and I returned to academia with a determination to make changes that would enhance student learning and engagement around issues of equity. This article will provide an account of one teacher educator's journey in becoming a culturally responsive teacher herself, while also trying to develop future teachers as educators committed to teaching with an equity lens. The article highlights research-based pedagogical practices that support preservice teacher learning to promote equity in education. 


\section{Historical and Current Inequities in Education}

The discrepancies in racial representation between teachers and students call for diversifying the curriculum, so all students might benefit from exposure to multiple perspectives. Research indicates potential benefits to the integration of culturally responsive teaching practices with preservice teacher candidates, such as increased self-awareness regarding diversity (Nganga, 2015) and an increased commitment to teaching in urban schools (Conaway, Browning, \& Purdum-Cassidy, 2007). There are numerous causes for discrepancies in racial diversity in teacher preparation, from the historical repercussions of Brown v. the Board of Education of Topeka Kansas (1954), which inadvertently resulted in the radical depletion of teachers and principals of color with the closing of all-Black schools and the firing and nonrehiring of Black teachers (Lash \& Ratcliffe, 2014; Mondale \& Patton, 2001) to the lack of recruitment, monetary and emotional support, and role models of color (Landis, Ferguson, Carballal, Kuhlman, \& Squires, 2007). Studies show that students of color taught by teachers of color performed better in math and reading, had higher graduation rates, higher attendance, higher tests scores, and attended college at higher rates (Redding, 2019; Vilson, 2015). The need to diversify racial representation in our teaching force is long overdue.

Preparing teachers to be critical pedagogues and to implement culturally sustaining pedagogy in their own practices is one avenue for advancing inclusive perspectives, policies, and practices in the field of education. Engaging with critical pedagogy as an integrated part of teacher preparation can help preservice educators become aware of hidden curriculum bias, which can include discrimination, prejudice, racism, sexism, stereotypes, tokenism, ethnocentrism, exotica, inappropriate language, and the use of out-of-date material (Howe \& Lisi, 2017). Furthermore, research has found that curriculum that promotes sexism can perpetuate a power imbalance between men and women, as indicated in higher SAT scores in male high school graduates than female, girls becoming less career focused, and less likely to engage in math and science courses (McLaren, 2017). Critical pedagogy promotes the empowerment of students: "not only helping students to understand and engage the world around them, but also enabling them to exercise the kind of courage needed to change the social order where necessary" (McLaren, 2017, p. 69). An integration of critical pedagogies can help teachers work toward a critical consciousness, where they "think about," wonder "what if," and explain why (Gay, 2010, p. 231).

\section{Professional Learning to Promote Change}

Learning to become a culturally responsive and sustaining educator is a process, and professional development in the form of a conference is only one avenue to help educators learn and grow as equity-focused educators. I attended my first National Association for Multicultural Education (NAME) conference in November 2018. The theme of this multicultural education conference was, "How many more 'til we rise up?" The conference was in Memphis, Tennessee, honoring the $50^{\text {th }}$ anniversary of Dr. Martin Luther King, Jr.'s 1968 assassination at a hotel in Memphis. Despite living for one year in Nashville as part of the Jesuit Volunteer Corps, the only time I had spent in Memphis was a brief lunch at Beale Street's BB King's Blues Club when driving through town. As a White woman from the Pacific Northwest, I knew the trek South would be a culturally immersive experience for me, but I did not anticipate the discomfort I would feel in this new space, largely stemming from my own lived experiences of White privilege. According to the most recent population estimates (United States Census Bureau, 2018a), Memphis is 29\% White and 64\% Black or African American, which differs greatly from 
the racial makeup of my home city of Portland, Oregon (see Table 1). The lack of racial diversity in Oregon largely stems from nineteenth century laws of racial exclusion, including a constitutional clause prohibiting blacks from being in the state and owning property (Black exclusion laws in Oregon, 2018).

Table 1

Population Demographic Data Comparison

\begin{tabular}{lcc}
\hline & Portland & Memphis \\
\hline Population & 647,805 & 652,236 \\
White & $77 \%$ & $29 \%$ \\
Black or African American & $6 \%$ & $64 \%$ \\
Hispanic or Latino & $10 \%$ & $7 \%$ \\
\hline
\end{tabular}

(U.S. Census Bureau, 2018a, 2018b)

My discomfort challenged me to reflect on my own biases and to seek the roots of my fears. I asked myself how my students feel on a daily basis when they identify as a member of an underrepresented group. I asked questions and engaged with educators, research, and resources that could help me find answers and avenues to address these dilemmas. The conference left me with more questions and a deeper discomfort in my own growth and development, yet I also left with more determination to make positive changes in my own practice and in the broader field of education. I remembered what I teach my students: expect and accept non-closure when engaging with topics about race and equity (Singleton \& Linton, 2006).

The NAME conference highlighted the intersectionality and complexity surrounding CSP. The 2018 conference began with a keynote by educator, researcher, and author, Beverly Tatum. One of the key take-aways in Tatum's lecture was the words, "Teachers are not color blind; they are color silent." She described the fear and uncertainty many teachers feel to speak about race and injustice. Her book Why are all the Black kids sitting together in the cafeteria? And other conversations about race (2017) addresses difficult topics surrounding race by sharing professional and personal stories that can help teachers reach all students. Tatum's lecture was only the beginning of my pedagogical and cultural inspiration at the conference.

The next few days were filled with more opportunities for growth, including learning how to integrate the music and themes from the Broadway hit Hamilton (Miranda, 2016) into a content methods course, how to analyze case studies through a social justice lens, and Christine Sleeter's story about repaying a Colorado Native American tribe for the land her ancestors colonized (Sleeter, 2013). Additionally, Memphis offers the National Civil Rights Museum at the Lorraine Motel, which is a powerful historic and emotional immersive learning experience. I left the South feeling a paradox of emotions: inspired, yet inadequate; proud of the field of Education, yet shameful of the inequities in the system; most of all, perhaps, I felt moved to change my own practice.

This article is a reflection on these pedagogical changes, including diversifying curriculum, engaging with community and K-12 partners, using innovative technologies, and self-reflection. Many of the practices that will be highlighted in this article were already part of my teaching pedagogy, yet I now view them through an equity lens. My hope is that sharing these strategies, in addition to the continued struggle of becoming an effective multicultural educator, will inspire other teacher educators to grow their own practices and self-reflection in order to prepare the next generation of culturally sustaining teachers who will then inspire the next generation of teachers. 


\section{Practice Change One: Update My Textbook}

The first major change I made upon returning from NAME was to analyze my own curriculum for bias, both hidden and explicit. Research has found that most textbooks are still a core part of the curriculum, and they typically highlight the European American perspective while also excluding information about underrepresented racial and social groups (Sleeter \& Grant, 1991). Additionally, even multicultural textbooks can promote inclusivity and exclusivity of various cultural groups based on their use of pronouns, such as "we" and "they" (Uzum, Yazan, \& Selvi, 2018). An awareness of the far-reaching impact of the textbook calls for teacher educators to be conscientious and deliberate consumers.

One of my core classes is Curriculum and Instruction for elementary preservice teachers. The first time I taught the course, I used a text that provided a cursory overview of many key topics in teaching and learning without diving deeply into any one topic. There was one chapter in the text that explicitly discussed cultural diversity as a separate topic rather than an integrated theme throughout all topics about teacher preparation. I decided to make a textbook change and adopted Howe and Lisi's (2017) text, Becoming a Multicultural Educator: Developing Awareness, Gaining Skills, and Taking Action. This text integrates an equity lens into all the same topics I had taught the previous year. Cultural diversity and historical perspectives on systemic racism and oppression are woven naturally through the text to provide preservice educators with the foundational knowledge they need to understand and navigate issues surrounding equity. We were able to learn how to lesson plan by actually reading and writing equity-based lessons and curricular material. Additionally, Howe and Lisi's (2017) text also includes biographies of multicultural educators of many different races and ethnicities, which promoted further self-reflection among our teacher candidates. The text offers reflective questions that students of all backgrounds can connect to, rather than a narrow focus on helping White students understand racism. For instance, one exercise called "The Meaning of My Name" (p. 131) asks various questions such as, "Why were you given the name you have? What do you find challenging about your name?" Students of any racial and ethnic background can engage reflectively with this task. The inclusive nature of the text, which also maintains a consistent focus on multicultural education, helped students reflect on their own positionality and how it impacts the way they plan lessons and interact with their K-12 students. Perhaps this first step of updating my textbook will help reduce the power imbalances highlighted by McClaren (2017), Sleeter (2016), and Williams (2016) and encourage students to consider social changes that can disrupt systems of inequity.

\section{Practice Change Two: Collaborate with Community Partners}

Since I began teaching in higher education, I have worked hard to partner with community members as a means of diversifying and enhancing curriculum. The NAME conference reminded me of the collective knowledge and experiences that community partners can bring to the higher education classroom. Research across content areas highlights the value of community partnerships in education (i.e.: Algie \& Rowland, 2007; Waddell, 2013). Waddell (2013) found teacher candidates demonstrated critical identity development following urban immersion experiences with community partners, especially in developing an awareness of naivety and privilege and an increase in self-reflection. Community speakers in teacher preparation programs can further promote inclusion, as seen in one study that brought guest speakers into a course to educate teachers about lesbian, gay, and bisexual students and 
challenges they may face in educational settings (Larrabee \& Morehead, 2010). Bringing an outside expert into a class can enhance student learning.

One key community partner in my own teaching practice has been Rethinking Schools, which publishes numerous culturally relevant teacher resources, including textbooks and a magazine. Bill Bigelow, an author and editor for Rethinking Schools, has conducted a workshop in my preservice teacher preparation classes multiple times that focuses on teaching with cultural relevance. Following a workshop on Rethinking Columbus (Bigelow \& Peterson, 1998), qualitative preservice teacher candidate data were analyzed to investigate the impact of the workshop and found that students were able to generate numerous teaching strategies for integrating culturally relevant teaching regarding teaching Columbus into their elementary school classrooms (Smith, Ralston, \& Waggoner, 2018). For example, the theme of "Empower the Voiceless" was demonstrated in the following preservice teacher idea:

First, I would have them ask and answer questions like, "Whose side is this written by? Who do we not hear from? How would we feel if we were the Native Americans?" I would also make sure to have multiple types of texts for them to read so that they can observe and think about the differences on their own and form their own opinions. Following the workshop, preservice teachers demonstrated the ability to plan lessons focused on teaching how to read critically for hidden messages and values.

Another community partner from Rethinking Schools is Linda Christensen. I used her textbook, Reading, Writing, and Rising Up (Christensen, 2017) in a Language Arts Methods class, and she graciously agreed to come to my class to speak about integrating culturally relevant teaching into secondary language arts classes. My students were star-struck by Linda's presence, and they were engaged and appreciative of her wit and wisdom. Linda's real-life experiences working with diverse student populations, in addition to her hands-on activities during presentations, captivates and inspires teachers of any age and experience level. These community partners are able to deepen learning in my teacher preparation classes and help provide future educators with practical tools to help them grow into culturally responsive teachers.

\section{Practice Change Three: Listen \& Share Voices of K-12 Educators}

In addition to community partners, there is also much power in partnering with K-12 educators who are still engaged in the day-to-day grind and glory of teaching K-12 learners. Numerous educators have collaborated to help provide my preservice students with diverse perspectives. The following K-12 collaborations have enhanced my teacher preparation curriculum:

Maker Space Project. Maker spaces have become the trend in Science Technology Engineering and Math (STEM) education, and there has also been a focus on how these spaces can engage underserved communities in solving real-world problems (Calabrese Barton \& Tan, 2018). If teacher preparation programs can partner with K-12 schools and help provide resource supports to engage students with hands-on maker learning experiences, perhaps these real-world problems can be solved in the classroom.

This semester, I have forged a partnership with an elementary school teacher who manages a Maker Space at his school. He first came to our university to tour our own maker space with preservice educators. He gave a talk to my students on Maker Spaces to provide a research base for this work. The following week, my students and I engaged on a field trip to his elementary school, where we were able to actually complete two maker space projects: a wind- 
powered car and a trebuchet. The learning was hands-on, active, fun, and authentic. Both the students and I were inspired to integrate maker learning in future instructional practice.

Restorative Justice Workshop. Exposing preservice teachers to restorative justice (RJ) as a form of classroom management, in addition to a community building and inclusive method of teaching provides them with alternatives to exclusionary practices that disproportionately impact students of color (American Psychological Association, 2008; González, 2012). A metaanalysis on RJ practices in schools (Latimer, Dowden, \& Muise, 2005) found these practices to be significantly more effective than nonrestorative, traditional discipline systems, based on the following factors: victim and offender satisfaction, restitution compliance, and recidivism.

An elementary school teacher and coach, who has been trained on and researched restorative justice, came to speak to my students about the research behind restorative justice and how to incorporate the practice in a classroom community. The workshop involved hands-on engagement in an RJ circle and practical tools for teachers to use in their own classrooms.

Proficiency Grading. Proficiency grading has grown in popularity over the past decade (Kalnin, 2014), and preservice educators need exposure to using this method to reach all students and remain competitive and prepared for the job market. A student achievement specialist came to my Assessment course to expose my preservice teachers to proficiency grading as an assessment framework for districts, schools, and classrooms. One potential positive outcome of this method of assessment is the individualization for students (Scriffiny, 2008). Teachers and students assess progress to meeting a particular standard, which can help the teacher adjust instruction to meet the specific learning needs of a diverse class of students.

Critical Race Theory. A high school administrator presented a hands-on workshop in my Master of Arts in Teaching (MAT) Capstone Research course, which provided a research and historical background to Critical Race Theory (CRT). Students were required to read an article in advance, and they learned methods for incorporating CRT as a framework for their research projects. Understanding CRT can provide a foundation for teachers interested in integrating critical pedagogies in their own practices, such as critical literacy (Freire, 1970), critical feminism (De Saxe, 2016), or critical professional development (Kohli, Picower, Martinez, \& Ortiz, 2015). My goal is to continue to partner with K-12 educators in order to expose my students to diverse perspectives and to maintain a connection between academia and $\mathrm{K}-12$ education.

\section{Practice Change Four: Integrate New Innovative Technology, and Push Into K-12 Classrooms}

As an educator of future teachers, I try to model best practices for my students, which includes integrating new technologies into my teaching practice, even when doing so challenges my own comfort and confidence. The most recent innovative technology-based instructional practice that has exposed my students to a new technology while also focusing on accommodating for diverse learners is the use of Virtual Reality (VR).

Thanks to a technology innovation grant provided by my university, a team of colleagues and I embarked on a teaching and research project with our preservice teachers that involved the integration of VR into teacher preparation courses. We purchased a VR education kit, which included a set of 10 headsets, 10 Google 'phones,' a charging station, a Wi-Fi adaptor, and a Google tablet. We introduced our students to the technology in a hands-on presentation, which included an overview of the literature on VR and potential student learning outcomes. We then required students to partner with classmates in the same discipline and plan a lesson simulation 
that utilized the VR technology as part of the learning activities. These lessons were taught throughout the course. Students were thus exposed to numerous VR Google Expedition experiences. Students were also invited to check out the VR kit to use in their student teaching placement sites with their own K-12 students. To date, six students have taken advantage of this opportunity. Our faculty team has gathered data on these learning experiences and plan to publish this research project in the near future. Furthermore, students who both experienced the VR in a university class and also used it to teach as a teacher candidate with K-12 students were invited to co-present at a local education conference. The exposure to VR technology is unique in educational settings, and an integration of VR into our teacher preparation program has exposed future teachers to effective uses of VR for teaching and learning and also allowed K-12 students, whose schools have not allocated funding for such technology, to experience it firsthand.

Research on using virtual reality to enhance student learning suggests positive outcomes for education that promotes equity. VR can provide students who are economically disadvantaged with experiences they may otherwise never have, such as taking virtual field trips to museums or other countries (Barbara \& Gail, 2003; Stainfield, Fischer, Ford, \& Solem, 2010). The use of VR can also promote future careers in Science, Technology, Engineering, and Math (STEM) for students who may not otherwise be exposed to interactive and engaging technologies (Dieker, Grillo, \& Ramlakhan, 2012). Furthermore, preliminary research studies on VR technologies suggest that VR has the potential to positively impact social behaviors in students with Autism (Parsons \& Cobb, 2011; Parsons \& Mitchell, 2002). However, research on the impact of VR on student learning is limited (Grynszpan, Weiss, Perez-Diaz, \& Gal, 2014), which is another reason to support implementation in higher education.

\section{Practice Change Five: Continue Reading and Researching}

The NAME conference left me with a reading list of nearly 20 books. I checked out several to read over my winter break and was most inspired by bell hooks' (1994) Teaching to Transgress. Her reflective writings feel as relevant in 2019 as they were in 1994, and perhaps that is a result of my own journey of awakening. Her concept of engaged pedagogy rang true to me: "to teach in a manner that respects and cares for the souls of our students is essential if we are to provide the necessary conditions where learning can most deeply and intimately begin" ( $p$. 13). hooks draws on the work of Paulo Freire (1970) and Thich Nhat Hanh (1991) and calls on teachers to be courageous and committed to self-actualization, so that our own teaching will empower students.

Furthermore, as I teach courses in instructional practice, assessment, and Master's and Doctoral level research, I hope to continue encouraging my students to read about, research, and practice equitable teaching practices. Change is slow, but I hope to be part of a positive change in our systems of education.

\section{Areas for Continued Personal and Professional Improvement}

Despite the practice changes that I have implemented, and the recognition of the cultural value in pedagogy that I was already engaged in, I know I still have many places to grow as a culturally relevant and culturally sustaining educator. Some of these areas are still blind spots to me: I know that I do not know. However, I am an adult learner who wants my learning experiences to be applicable and meaningful, and I believe that seeking methods for integrating equity into teacher preparation programs is meaningful, relevant, and critical work. In her article 
Culturally Relevant Pedagogy 2.0: A.k.a. the Remix, Ladson-Billings (2014) highlights her experiences with well-intentioned teachers who strive to integrate culturally responsive teaching into their practices, yet "they rarely pushed students to consider critical perspectives on policies and practices that may have direct impact on their lives and communities" (p. 78). This lack of sociopolitical engagement in the pedagogical process is one of my areas for improvement. How can I more deeply challenge my students to consider systemic changes that can have long-term impacts on systems of injustice? How can I create critical thinkers who are unafraid to engage with difficult issues of our current day?

New and veteran teachers alike have access to countless tools and resources that can help us become stronger pedagogues. For instance, Ladson-Billings (2014) encourages integrating pop culture through hip-hop music, poetry, and art into our pedagogy, and she embraces the expanded term culturally sustaining pedagogy. The sustainability aspect embraces the multiple individual identities of our students, yet it expands student identities beyond national borders, highlighting the global and international identities present in our students and our cultures. CSP calls on educators to seek an understanding of the dynamic nature of student interactions with race, ethnicity, language, literacy, and culture (Paris \& Alim, 2017). With these foundational pedagogical and social perspectives, in addition to a consistent critical reflection, we can remain engaged educators, striving to understand ourselves in relationship to our students, our content, and our practice.

\section{Discussion}

Teacher preparation programs must continue to engage in the hard work of self-reflection and continued professional learning for higher education faculty on issues of equity and social justice. Williams' (2016) method of radical honesty in engaging college students in discussions about race, gender, power, difference, and oppression is a place where all teacher educators can begin. She models truth-telling regarding her own multiple identities to set the "expectation for the type of deep awareness, reflexivity, and critical thought [she] expects from [herself] and [her] students" (p. 72). Furthermore, Tuitt (2016) advocates for validating the lived experiences of students as a means for promoting inclusion and leveraging intersectional identities to create safe learning environments. White faculty members in higher education, including myself, must be conscientious about marginalizing students of color when promoting "diversity curricula that focus on raining consciousness among White students, in the process overlooking the intellectual needs of students of color" (Sleeter, 2016, p. 17). Sleeter (2016) advocates for interracial collaboration among teaching colleagues and broad choices for student readings and focusing on challenging questions, such as what is institutional racism and intersectionality. Further, utilizing students as allies in learning can promote student engagement and satisfaction (Richardson \& Radloff, 2014). In addition to building ally-ship among students, Predominantly White Institutions (PWIs) must seek methods for helping students navigate race, such as structured dialogues and service learning opportunities (Campbell, 2016). Each of us comes to the work of equity and teacher preparation from our own lived experiences, and we all have places to learn and grow.

\section{Conclusion}

There is a continued need for more research on the impact of culturally sustaining pedagogy, both on student learning and on teacher practice. The limited research that does exist surrounding culturally relevant and sustaining pedagogy suggests positive impacts on student engagement (Hill, 2009), enhanced student perceptions of their teachers and an increase in effort 
in class (Howard, 2001), and improved standardized test scores (Cammarota \& Romero, 2009; Sleeter, 2012). However, preparing culturally sustaining teachers for diverse classrooms of students is a complex process, and we must be cautious of oversimplifying understandings of how to be a teacher who is culturally engaged (Sleeter, 2012).

We must do the work needed to educate and form preservice and in-service teachers who can connect with students in meaningful ways that go deeper than content learning, so that we can continue to bridge educational inequities and inspire the next generation. Critical reflection is essential for exposing both internal and institutional biases that can impede the diversity of students entering and excelling in our programs. We can do better for our students and our future.

\section{References}

Algie, J. \& Rowland, J. K. (2007). A guest lecturing program to improve students' applied learning. Proceedings of the Australian and New Zealand Marketing Academy Conference (pp. 1-6). Dunedin, New Zealand: Australian and New Zealand Marketing Academy.

American Psychological Association Zero Tolerance Task Force. (2008). Are zero tolerance policies effective in the schools: An evidentiary review and recommendations. American Psychologist, 63(9), 852-862.

Anglás Grande, S. M. (2017). American Indian geographies of identity and power: At the crossroads of Indígena and Mestizaje. In A. Darder, R. D. Torres, \& M. Baltodano (Eds.), The critical pedagogy reader (Third ed.) (pp. 216 - 240). New York, NY: Routledge.

Barbara, K.E., \& Gail, T. (2003). Virtual field trips: Best practices. International Journal of Instructional Media, 30(2), 177-193.

Black exclusion laws in Oregon. (2018, March). Portland State University and the Oregon Historical Society. Retrieved from https://www.oregonencyclopedia.org/articles/exclusion_laws/\#.XNRlspNKiu4

Bigelow, B., \& Peterson, B. (1998). Rethinking Columbus: The next 500 years (2nd ed.). Milwaukee, WI: Rethinking Schools.

Brown v. Board of Education of Topeka Kansas, 347 U.S. 483 (1954).

Calabrese Barton, A., \& Tan, E. (2018). STEM-rich maker learning: Designing for equity with youth of color. New York, NY: Teachers College Press.

Campbell, B. (2016). Utilizing an African American studies course to garner critical consciousness among students: Considerations for improving campus climate. Journal of Pan African Studies, 9(8), 26.

Cammarota, J., \& Romero, A. (2009). The social justice education project: A critically compassionate intellectualism for Chicana/o students. In W. Ayers, T. Quinn \& D. Stovall (Eds.), Handbook for social justice education (pp. 465-476). New York, NY: Lawrence Erlbaum.

Christensen, L. (2017). Reading, writing, and rising up: Teaching about social justice and power of the written word. Milwaukee, WI: Rethinking Schools.

Conaway, B. J., Browning, L. J., \& Purdum-Cassidy, B. (2007). Teacher candidates' changing perceptions of urban schools: Results of a 4-year study. Action in Teacher Education, 29(1), 20-31. https://doi.org/10.1080/01626620.2007.10463436

De Saxe, J. (2016). Critical feminism and critical education: An interdisciplinary approach to teacher education (Routledge research in teacher education). New York: Routledge. 
Dewey, J. (1997). Experience and education (2nd ed.). New York: Touchstone.

Dieker, L., Grillo, K., \& Ramlakhan, N. (2012). The use of virtual and simulated teaching and learning environments: Inviting gifted students into science, technology, engineering, and mathematics careers (STEM) through summer partnerships. Gifted Education International, 28(1), 96-106.

Frankerberg, E., Lee, C., \& Orfield, G. (2003). A multiracial society with segregated schools: Are we losing the dream? Cambridge, MA: Civil Rights Project, Harvard University.

Freire, P. (1970). Pedagogy of the oppressed. New York: Continuum.

Gay, G. (2010). Culturally responsive teaching: Theory, research, and practice (2nd ed., Multicultural education series. New York: Teachers College.

González, T. (2012). Keeping kids in schools: Restorative justice, punitive discipline, and the school to prison pipeline. Journal of Law \& Education, 41(2), 281-335.

Grynszpan, O., Weiss, P. L., Perez-Diaz, F., \& Gal, E. (2014). Innovative technology-based interventions for autism spectrum disorders: A meta-analysis. Autism: The International Journal of Research and Practice, 18(4), 346-361.

Hanh, T. N. (1991). Peace is every step: The path of mindfulness in everyday life. New York: Bantam.

Hill, M. L. (2009). Wounded healing: Forming a storytelling community in hip-hop lit. Teachers College Record, 111, 248-293.

hooks, b. (1994). Teaching to transgress: Education as the practice of freedom. New York: Routledge.

Howard, T. C. (2001). Telling their side of the story: African American students' perceptions of culturally relevant teaching. Urban Review, 33(2), 131-149.

Howe, W., \& Lisi, P. (2017). Becoming a multicultural educator: Developing awareness, gaining skills, and taking action (Second ed.). Los Angeles: Sage Publications.

Kalnin, J. S. (2014). Proficiency-based grading: Can we practice what they preach? AILACTE Journal, 11(1), 19-36.

Kohli, R., Picower, B., Martinez, A. N., \& Ortiz, N. (2015). Critical professional development: Centering the social justice needs of teachers. The International Journal of Critical Pedagogy, 6(2).

Larrabee, T. G., \& Morehead, P. (2010). Broadening views of social justice and teacher leadership: Addressing LGB issues in teacher education. Issues in Teacher Education, 19(2), 37-52.

Ladson-Billings, G. (1995). Toward a theory of culturally relevant pedagogy. American Educational Research Journal, 32(3), 465-491.

Ladson-Billings, G. (2014). Culturally relevant pedagogy 2.0: A.k.a. the remix. Harvard Educational Review, 84(1), 74-84.

Landis, M., Ferguson, A., Carballal, A., Kuhlman, W., \& Squires, S. (2007). Analyzing an urban university's diversity dilemma. Teacher Education Quarterly, 34(4), 121-136.

Lash, M., \& Ratcliffe, M. (2014). The journey of an African American teacher before and after Brown v. Board of Education. The Journal of Negro Education, 83(3), 327-337,426. https://doi.org/10.7709/jnegroeducation.83.3.0327

Latimer, J., Dowden, C., \& Muise, D. (2005). The effectiveness of restorative justice practices: A meta-analysis. Prison Journal, 85(2), 127-144.

McLaren, P. (2017). Critical pedagogy: A look at the major concepts. In Darder, A., Torres, 
Rodolfo D., \& Baltodano, M. (Eds.), The critical pedagogy reader (Third ed.) (pp. 5678). New York: Routledge.

Mezirow, J. (2003). Transformative learning as discourse. Journal of Transformative Education, 1(1), 58-63.

Miranda, L. (2016). Hamilton: An American musical. In J. McCarter (Ed.), Hamilton: The revolution (pp. 23-26). New York: Grand Central Publishing.

Mondale, S., \& Patton, S. B. (Eds.) (2001). School: The story of American public education. Boston: Beacon Press.

Nganga, L. (2015). Culturally responsive and anti-biased teaching benefits early childhood preservice teachers. Journal of Curriculum and Teaching, 4(2), 1-16. https://doi.org/10.5430/jct.v4n2p1

Paris, D., \& Alim, H. S. (2017). Culturally sustaining pedagogies: Teaching and learning for justice in a changing world (Language and literacy series). New York: Teachers College Press.

Parsons. S., \& Cobb, S. (2011). State-of-the art of virtual reality technologies for children on the autism spectrum. European Journal of Special Needs Education, 26(3): 355-366.

Parsons, S., \& Mitchell, P. (2002). The potential of virtual reality in social skills training for people with autism spectrum disorders. Journal of Intellectual Disability Research, 46: $430-443$.

Redding, C. (2019). A teacher like me: A review of the effect of student-teacher racial/ethnic matching on teacher perceptions of students and student academic and behavioral outcomes. Review of Educational Research, 89(4), 499-535. https://doi.org/10.3102/0034654319853545.

Richards, H. V., Brown, A. F., \& Forde, T. B. (2007). Addressing diversity in schools: Culturally responsive pedagogy. TEACHING Exceptional Children, 39(3), 64-68.

Richardson, S., \& Radloff, A. (2014). Allies in learning: Critical insights into the importance of staff-student interactions in university education. Teaching in Higher Education, 19(6), 603-615.

Scriffiny, P. L. (2008). Seven reasons for standards-based grading. Educational Leadership, 66(2), 70-74.

Singleton, G., \& Linton, C. (2006). Courageous conversations about race: A field guide for achieving equity in schools. Thousand Oaks, CA: Corwin Press.

Sleeter, C. E. (2013, July 12). Racism, inheritance and family financial aid. Retrieved from http://christinesleeter.org/inheritance-and-family-financial-aid/

Sleeter, C. E. (2016). Learning to work while white to challenge racism in higher education. In N. Joseph, C. Haynes, \& F. Cobb, (Eds.) Interrogating whiteness and relinquishing power: White faculty's commitment to racial consciousness in STEM classrooms (Social justice across contexts in education; v. 1) (pp. 13 - 26). New York: Peter Lang.

Sleeter, C. E. (2012). Confronting the marginalization of culturally responsive pedagogy. Urban Education, 47(3), 562-584.

Sleeter, C. E., \& Grant, C. A. (1991). Race, class, gender, and disability in current textbooks. In Apple, M. W. \& Christian-Smith, L. K. (Eds.), The politics of the textbook (pp. 78-110). New York: Routledge.

Smith, M. D., \& Glenn, T. L. (2016). "Reflecting on the reflection...": Exploring teacher candidates' assumptions of self and others through facilitated reflection. Teacher Educator, 51(4), 314-334. 
Smith, R., Ralston, N.C., \& Waggoner, J. (2018). Impact of culturally responsive teaching workshop on pre-service teachers: How to teach Columbus from multiple perspectives. Association of Independent Liberal Arts Colleges for Teacher Education Journal.

Stainfield, J., Fischer, P., Ford, B., \& Solem, M. (2010). International virtual field trips: A new directions? Journal of Geography in Higher Education, 24(2), 255-262.

Tatum, B. (2017). Why are all the black kids sitting together in the cafeteria? And other conversations about race (Third trade paperback edition; Twentieth anniversary ed.). New York: Basic Books.

Taie, S., \& Goldring, R. (2018). Characteristics of public elementary and secondary school teachers in the United States: Results from the 2015-16 National Teacher and Principal Survey First Look (NCES 2017-072rev). U.S. Department of Education. Washington, DC: National Center for Education Statistics. Retrieved Jan. 31, 2019 from http://nces.ed.gov/pubsearch/pubsinfo.ap?pubid=2017072rev

Tuitt, F. (2016). Inclusive pedagogy 2.0: Implications for race, equity, and higher education in a global context. In F. Tuitt, C. Haynes, \& S. Stewart (Eds.), Race, equity, and the learning environment: The global relevance of critical and inclusive pedagogies in higher education (First ed.) (pp. 205 - 221). Sterling, Virginia: Stylus Publishing, LLC.

Uzum, B., Yazan, B., \& Selvi, A.F. (2018). Inclusive and exclusive uses of we in four American textbooks for multicultural teacher education. Language Teaching Research, 22(5), 625647.

U.S. Department of Education. (2014). National Center for Education Statistics, Common Core of Data (CCD). State Nonfiscal Survey of Public Elementary and Secondary Education.

United States Census Bureau. (2018a). QuickFacts Memphis city, Tennessee. [Data file]. Retrieved from https://www.census.gov/quickfacts/memphiscitytennessee

United States Census Bureau. (2018b). QuickFacts Portland city, Oregon. [Data file]. Retrieved from https://www.census.gov/quickfacts/fact/table/portlandcityoregon/PST045218

Vilson, J. L. (2015). The need for more teachers of color. American Educator, 39(2), 27-31.

Waddell, J. H. (2013). Communities as critical partners in teacher education: The impact of community immersion on teacher candidates' understanding of self and teaching in urban schools. Current Issues in Education, 16(2), 16.

Williams, B. (2016). Radical honesty: Truth-telling as pedagogy for working through shame in academic spaces. In F. Tuitt, C. Haynes, \& S. Stewart (Eds.), Race, equity, and the learning environment: The global relevance of critical and inclusive pedagogies in higher education (First ed.) (pp. 71 - 82). Sterling, Virginia: Stylus Publishing, LLC. 